\title{
PENDIDIKAN GIZI SEBAGAI SUATU UPAYA PEMENUHAN ZAT GIZI DARI SAYUR DAN BUAH PADA ANAK SEKOLAH DASAR
}

\author{
Ronasari Mahaji Putri ${ }^{1}$, Verarica Silalahi ${ }^{2}$, Nia Lukita Ariani ${ }^{3}$ \\ Program Studi Ilmu Keperawatan Universitas Tribhuwana Tunggadewi ${ }^{1,2,3}$ \\ Email:putrirona@gmail.com
}

\begin{abstract}
The purpose of this study was to analyze the nutritional education in an effort to fulfill elementary school childrens'nutrients from vegetables and fruits. This is a quasy experiment. Intervention that given to teachers was nutritional education in Merjosari 2 Public Elementary School Malang, Merjosari 3 Public Elementary School Malang and Merjosari 5 Public Elementary School Malang. Data on 102 students' consumption of vegetables, fruits and nutrients obtained from 24-hour food recall converted from Nutrisurvey and then processed using the Wilcoxon test. There wasa significant difference in fruit consumption and vitamin $C(p<0.05)$ and there was no difference in consumption of vegetables and other nutrients (vitamin $A$, vitamin B1, vitamin B6, iron, calcium and phosphorus) ( $>>0.05)$. To increase childrens'consumption of vegetables and other nutrients, it is necessary to provide nutritional education to parents, especially mother.
\end{abstract}

Keywords: Vegetables and fruits, nutrients, nutritional education, elementary school children

\section{PENDAHULUAN}

Gizi merupakan salah satu faktor yang memengaruhi tumbuh kembang anak. Bila bayi yang dilahirkan kekurangan zat gizi, maka pertumbuhan dan perkembangan anak akan terganggu(Supariasa et al., 2013). Kebutuhan zat gizi pada masa anak-anak bertitik berat pada kebutuhan vitamin dan mineral selain energi dan protein. Meskipun dua zat gizi ini juga terdapat dalam pangan hewani, namun, vitamin dan mineral lebih banyak terkandung dalam sayur dan buah (Kemenkes, 2014b). Vitamin dan mineral penting untuk pertumbuhan dan perkembangan normal (Departemen Gizi dan Kesehatan Masyarakat UI, 2014).Vitamin dan mineral yang terkandung dalam sayuran dan buah-buahan berperan sebagai antioksidan atau penangkal senyawa jahat dalam tubuh. Berbeda dengan sayuran, buah-buahan juga menyediakan karbohidrat terutama berupa fruktosa dan glukosa. Sayur tertentu juga menyediakan karbohidrat, seperti wortel dan kentang sayur. Sementara buah tertentu juga menyediakan lemak tidak jenuh seperti buah alpokat dan buah merah.Semakin matang buah yang mengandung karbohidrat semakin tinggi kandungan fruktosa dan glukosanya, yang dicirikan oleh rasa yang semakin manis (Kemenkes, 2014b). 
Konsumsi sayur dan buah yang dianjurkan oleh WHO setidaknya $400 \mathrm{gr}$ perorang perhari, yang terdiri dari 250 gr sayur (setara dengan $2 \frac{1}{2}$ porsi atau $2 \frac{1}{2}$ gelas sayur setelah dimasak dan ditiriskan) dan 150 gr buah (setara dengan 3 buah pisang ambon ukuran sedang atau $1 \frac{1}{2}$ potong pepaya ukuran sedang atau 3 buah jeruk ukuran sedang). Bagi orang Indonesia dianjurkan konsumsi sayuran dan buahbuahan 300-400 gr per orang per hari bagi anak balita dan anak usia sekolah, dan 400-600 gr per orang per hari bagi remaja dan orang dewasa. Sekitar dua pertiga dari jumlah anjuran konsumsi sayuran dan buah-buahan tersebut adalah porsi sayur (Kemenkes, 2014b).

Khusus kepada anak usia sekolah, yaitu usia 6-9 tahun dianjurkan untuk mengonsumsi sayuran dan buah-buahan secara bervariasi sehingga diperoleh beragam sumber vitamin ataupun mineral serta serat, dan melipatgandakan konsumsi sayur dan buah, baik dalam bentuk segar maupun yang sudah diolah. Porsi sayur dan buah yang dianjurkan adalah 3 porsi. Khusus kepada anak usia 1012 tahun dianjurkan untuk mengonsumsi beragam makanan untuk memenuhi kebutuhan zat gizi mikro (vitamin dan mineral) yaitu zat besi dan asam folat (Kemenkes, 2014b).

Kandungan vitamin dalam sayur dan buah terbanyak adalah vitamin A, vitamin C, vitamin B1, dan vitamin B6, serta kandungan mineral terbanyak adalah besi, kalsium, dan fosfor (Supariasa et al., 2013). Kementerian Kesehatan mengeluarkan peraturan mengenai Angka Kecukupan Gizi (AKG) yang Dianjurkan bagi bangsa Indonesia berdasarkan kelompok umur yang tertuang dalam PMK RI Nomor 75 Tahun 2013. Peraturan ini menganjurkan AKG vitamin dan mineral untuk kelompok umur 7-9 tahun masing-masingvitamin A $500 \mathrm{mcg}$, vitamin C 45 $\mathrm{mg}$, vitamin B1 0,9 mg, vitamin B6 1,0 mg, besi $10 \mathrm{mg}$, kalsium $1.000 \mathrm{mg}$ dan fosfor $500 \mathrm{mg}$. Untuk laki-laki kelompok umur 10-12 tahun masing-masing vitamin A $600 \mathrm{mcg}$, vitamin C $50 \mathrm{mg}$, vitamin B1 1,1 mg, vitamin B6 1,3 mg, besi $13 \mathrm{mg}$, kalsium $1.200 \mathrm{mg}$ dan fosfor $1.200 \mathrm{mg}$, dan kelompok umur 13-15 tahun masingmasing vitamin A $600 \mathrm{mcg}$, vitamin C $75 \mathrm{mg}$, vitamin B1 1,2 mg, vitamin B6 1,3 $\mathrm{mg}$, besi $19 \mathrm{mg}$, kalsium $1.200 \mathrm{mg}$ dan fosfor $1.200 \mathrm{mg}$. Untuk perempuan kelompok umur 10-12 tahun masing-masing vitamin A $600 \mathrm{mcg}$, vitamin C $50 \mathrm{mg}$, vitamin B1 1,0 mg, vitamin B6 1,2 mg, besi $20 \mathrm{mg}$, kalsium $1.200 \mathrm{mg}$ dan fosfor $1.200 \mathrm{mg}$, dan kelompok umur 13-15 tahun masing-masing vitamin A $600 \mathrm{mcg}$, vitamin C $65 \mathrm{mg}$, vitamin B1 1,1 mg, vitamin B6 1,2 mg, besi $26 \mathrm{mg}$, kalsium 1.200 $\mathrm{mg}$ dan fosfor $1.200 \mathrm{mg}$ (Kemenkes, 2013).

Namun berdasarkan hasil Riskesdas 2013 diketahui bahwa konsumsi sayur dan buah Indonesia masih rendah, yaitu rata-rata konsumsi sayur sebesar 63,3\% dan rata-rata konsumsi buah sebesar 62,1\% dari porsi yang dianjurkan (Kemenkes, 2014a). Bahria dan Triyanti (2010) menemukan hasil yang serupa, yaitu remaja masih kurang konsumsi buah $(92,1 \%)$ dan sayur $(77,1 \%)$. Hermina dan Prihatini (2016) menemukan hasil rerata konsumsi sayur penduduk sebesar 70,0 
gram/orang/hari dan konsumsi buah sebesar 38,8 gram/orang/hari dan total konsumsi sayur dan buah penduduk 108,8 gram/orang/hari. Lebih lanjut, Kemenkes (2014b) menyebutkan bahwa konsumsi sayur dan buah yang rendah hampir berada di semua kelompok umur, baik di perkotaan maupun diperdesaan.

Berdasarkan penjelasan di atas, maka perlu dilakukan suatu upaya untuk meningkatkan pemenuhan zat gizi dari sayur dan buah pada anak terutama di usia sekolah. Salah satu upayanya adalah dengan memberikan intervensi pendidikan gizi berupa penyuluhan pada guru sekolah. Intervensi pendidikan gizi yang diberikan terbukti dapat meningkatkan skor pengetahuan subyek seperti yang ditemukan oleh Buamona (2016), Candra et al. (2013), Dwiriani et al. (2011), Nuryanto et al. (2014), dan Nurmasyita et al. (2015).

Pendidikan gizi yang diberikan diharapkan dapat mengubah sikap dan perilaku ke arah yang lebih baik, yang dalam hal ini adalah pemenuhan zat gizi dari sayur dan buah pada semua orang, khususnya pada anak sekolah dalam membantu tumbuh kembang anak.Penelitian ini bertujuan untuk mengkaji pendidikan gizi dalam upaya pemenuhan zat gizi dari sayur dan buah pada anak sekolah dasar.

\section{METODE PENELITIAN}

Penelitian ini merupakan penelitianquasy experiment. Intervensi yang diberikan berupa pendidikan gizi pada guru sekolah yang ada di SD Negeri Merjosari 2, SD Negeri Merjosari 3 dan SD Negeri Merjosari 5. Pendidikan gizi diberikan sebanyak satu kali selama 90 menit dengan bantuan booklet yang telah disiapkan oleh peneliti. Pemberian intervensi pendidikan gizi pada guru didasari oleh peran guru sebagai tokoh sentral dalam lingkungan sekolah, yang sejatinya digugu dan ditiru oleh murid. Selain sebagai penentu mutu pendidikan, guru juga berperan dalam penentu perilaku peserta didik. Hidup sehat, sebagai bagian dari nilai-nilai kebaikan, sejatinya dapat ditanamkan melalui pendidikan di sekolah.

Sebelum guru diberikan intervensi pendidikan gizi, siswa akan dilihat konsumsi sayur dan buahnya menggunakan formulir Food Recall 24 jam. Setelah intervensi, siswa akan kembali dilihat konsumsi sayur dan buahnya. Populasi dalam penelitian ini adalah seluruh siswa yang ada di SD Negeri Merjosari 3 dan SD Negeri Merjosari 5. Sampel diambil berdasarkan perhitungan rumus berikut ini :

$$
\left[\frac{\left(Z_{\alpha}+Z_{\beta}\right) x S_{d}}{d}\right]^{2}
$$

dengan $Z_{\alpha}(1,96), Z_{\beta}(0,842)$, Sd (100 gr), dan d (48,9 gr/hari). Hasil perhitungan menetapkan besar sampel minimal yang dibutuhkan untuk penelitian ini adalah 33 orang. Dikarenakan penelitian ini dilakukan di tiga lokasi, maka total besar sampel minimal adalah 99 orang.

Variabel independen dalam penelitian ini adalah pendidikan gizi sedangkan variabel dependen adalah porsi sayur dan buah serta zat gizi (vitamin A, vitamin $\mathrm{C}$, 
vitamin B1, vitamin B6, besi, kalsium, dan fosfor). Data porsi sayur dan buah serta zat gizi diperoleh dari Food Recall. Data inikemudian dikonversi menggunakan Nutrisurvey yang selanjutnya diolah menggunakan SPSS versi 22. Data porsi sayur dan buah yang didapat dibandingkan dengan porsi konsumsi sayur dan buah berdasarkan PMK No. 41 Tahun 2014 sedangkan data zat gizi dibandingkan dengan AKG berdasarkan PMK No. 75 Tahun 2013. Jika data yang didapat lebih atau sama dengan ketentuan, maka dikategorikan menjadi Terpenuhi, dan sebaliknya, bila data yang didapat kurang dari ketentuan, maka dikategorikan menjadi Tidak Terpenuhi. Untuk melihat perbedaan porsi sayur, porsi buah dan zat gizi antara sebelum dengan sesudah intervensi pendidikan gizi pada guru digunakan uji Wilcoxon.

\section{Karakteristik Subyek}

\section{HASIL DAN PEMBAHASAN}

Siswa yang menjadi subyek penelitian berjumlah 102 orang, masing-masing SD Negeri Merjosari 2 sebanyak 36 orang, SD Negeri Merjosari 3 sebanyak 33 orang dan SD Negeri Merjosari 5 sebanyak 33 orang. Pada SD Negeri Merjosari 2, pekerjaan ayah paling banyak adalah wiraswasta $(30,6 \%)$ sedangkan pekerjaan ibu adalah tidak bekerja atau Ibu Rumah Tangga (IRT) (58,3\%). Pada SD Negeri Merjosari 3, pekerjaan ayah paling banyak adalah buruh (51,5\%) sedangkan pekerjaan ibu adalah tidak bekerja atau Ibu Rumah Tangga (IRT) $(63,6 \%)$. Pada SD Negeri Merjosari 5, pekerjaan ayah paling banyak adalah wiraswasta $(33,3 \%)$ sedangkan pekerjaan ibu adalah tidak bekerja atau Ibu Rumah Tangga (IRT) $(60,6 \%)$ (Tabel 1).

Tabel 1. Distribusi Frekuensi Karakteristik Siswa

\begin{tabular}{|c|c|c|c|c|c|c|c|}
\hline \multirow{3}{*}{ No. } & \multirow{3}{*}{ Karakteristik } & \multicolumn{6}{|c|}{ Lokasi } \\
\hline & & \multicolumn{2}{|c|}{$\begin{array}{c}\text { SD Negeri } \\
\text { Merjosari } 2 \\
\end{array}$} & \multicolumn{2}{|c|}{$\begin{array}{c}\text { SD Negeri } \\
\text { Merjosari } 3\end{array}$} & \multicolumn{2}{|c|}{$\begin{array}{c}\text { SD Negeri } \\
\text { Merjosari } 5\end{array}$} \\
\hline & & $\mathbf{n}$ & $\%$ & $\mathbf{n}$ & $\%$ & $\mathbf{n}$ & $\%$ \\
\hline \multirow[t]{4}{*}{1.} & Jenis Kelamin & & & & & & \\
\hline & Laki-laki & 16 & 44,4 & 21 & 63,6 & 14 & 42,4 \\
\hline & Perempuan & 20 & 55,6 & 12 & 36,4 & 19 & 57,6 \\
\hline & Total & 36 & 100,0 & 33 & 100,0 & 33 & 100,0 \\
\hline \multirow[t]{5}{*}{2.} & Umur & & & & & & \\
\hline & $\leq 9$ tahun & 1 & 2,8 & 0 & 0,0 & 5 & 15,2 \\
\hline & 10-12 tahun & 35 & 97,2 & 32 & 97,0 & 28 & 84,8 \\
\hline & 13-15 tahun & 0 & 0,0 & 1 & 3,0 & 0 & 0,0 \\
\hline & & 36 & 100,0 & 33 & 100,0 & 33 & 100,0 \\
\hline \multirow[t]{8}{*}{3.} & Pekerjaan Ayah & & & & & & \\
\hline & a. PNS/TNI/Polri & 3 & 8,3 & 3 & 9,1 & 5 & 15,2 \\
\hline & b. Pegawai Swasta & 8 & 22,2 & 6 & 18,2 & 5 & 15,2 \\
\hline & c. Petani/Pedagang & 4 & 11,1 & 5 & 15,2 & 4 & 12,1 \\
\hline & d. Buruh & 8 & 22,2 & 17 & 51,5 & 6 & 18,2 \\
\hline & e. Wiraswasta & 11 & 30,6 & 2 & 6,1 & 11 & 33,3 \\
\hline & f. Tidak Bekerja & 2 & 5,6 & 0 & 0,0 & 2 & 6,1 \\
\hline & Total & 36 & 100,0 & 33 & 100,0 & 33 & 100,0 \\
\hline
\end{tabular}




\begin{tabular}{|c|c|c|c|c|c|c|c|}
\hline \multirow{3}{*}{ No. } & \multirow{3}{*}{ Karakteristik } & \multicolumn{6}{|c|}{ Lokasi } \\
\hline & & \multicolumn{2}{|c|}{$\begin{array}{c}\text { SD Negeri } \\
\text { Merjosari } 2\end{array}$} & \multicolumn{2}{|c|}{$\begin{array}{c}\text { SD Negeri } \\
\text { Merjosari } 3\end{array}$} & \multicolumn{2}{|c|}{$\begin{array}{c}\text { SD Negeri } \\
\text { Merjosari } 5\end{array}$} \\
\hline & & $\mathbf{n}$ & $\%$ & $\mathbf{n}$ & $\%$ & $\mathbf{n}$ & $\%$ \\
\hline \multirow[t]{8}{*}{4.} & Pekerjaan Ibu & & & & & & \\
\hline & a. PNS/TNI/Polri & 0 & 0,0 & 1 & 3,0 & 2 & 6,1 \\
\hline & b. Pegawai Swasta & 1 & 2,8 & 0 & 0,0 & 3 & 9,1 \\
\hline & c. Petani/Pedagang & 5 & 13,9 & 2 & 6,1 & 2 & 6,1 \\
\hline & d. Buruh & 1 & 2,8 & 5 & 15,2 & 4 & 12,1 \\
\hline & e. Wiraswasta & 8 & 22,2 & 4 & 12,1 & 2 & 6,1 \\
\hline & a. Tidak Bekerja (IRT) & 21 & 58,3 & 21 & 63,6 & 20 & 60,6 \\
\hline & Total & 36 & 100,0 & 33 & 100,0 & 33 & 100,0 \\
\hline
\end{tabular}

\section{Konsumsi Sayur dan Buah Siswa}

Porsi makan sayur siswa ditemukan lebih banyak dalam kategori tidak terpenuhi, baik sebelum $(92,2 \%)$ maupun sesudah $(96,1 \%)$ intervensi diberikan kepada guru sedangkan porsi makan buah ditemukan lebih banyak dalam kategori terpenuhi, baik sebelum $(58,8 \%)$ maupun sesudah $(75,5 \%)$ intervensi diberikan kepada guru. Seluruh zat gizi yang dikonsumsi siswa berada dalam kategori tidak terpenuhi sebelum intervensi diberikan kepada gurudan tetap berada dalam kategori tidak terpenuhi sesudah intervensi pendidikan guru, kecuali vitamin C $(53,9 \%)$ (Tabel 2).

Tabel 2. Konsumsi Sayur dan Buah serta Zat Gizi pada Siswa

\begin{tabular}{|c|c|c|c|c|c|c|}
\hline \multirow[b]{2}{*}{ No. } & \multirow[b]{2}{*}{ Konsumsi } & \multicolumn{2}{|c|}{ Food Recall 1} & \multicolumn{2}{|c|}{ Food Recall 2} & \multirow[b]{2}{*}{$p$} \\
\hline & & $\begin{array}{l}\text { Tidak } \\
\text { Terpenuhi } \\
(n ; \%)\end{array}$ & $\begin{array}{l}\text { Terpenuhi } \\
(\mathbf{n}, \%)\end{array}$ & $\begin{array}{l}\text { Tidak } \\
\text { Terpenuhi } \\
(\mathbf{n} ; \%)\end{array}$ & $\begin{array}{l}\text { Terpenuhi } \\
(\mathbf{n} ; \%)\end{array}$ & \\
\hline 1. & Sayur & $94(92,2)$ & $8(7,8)$ & $98(96,1)$ & $4(3,9)$ & 0,206 \\
\hline 2. & Buah & $41(40,2)$ & $60(58,8)$ & $25(24,5)$ & $77(75,5)$ & $0,004 *$ \\
\hline 3. & $\begin{array}{l}\text { Zat Gizi } \\
\text { Vitamin A } \\
\text { Vitamin C } \\
\text { Vitamin B1 } \\
\text { Vitamin B6 } \\
\text { Besi } \\
\text { Kalsium } \\
\text { Fosfor } \\
\end{array}$ & $\begin{array}{l}93(91,2) \\
66(64,7) \\
102(100,0) \\
102(100,0) \\
101(99,0) \\
102(100,0) \\
102(100,0)\end{array}$ & $\begin{array}{l}9(8,8) \\
36(35,3) \\
0(0,0) \\
0(0,0) \\
1(1,0) \\
0(0,0) \\
0(0,0)\end{array}$ & $\begin{array}{l}94(92,1) \\
47(46,1) \\
102(100,0) \\
101(99,0) \\
101(99,0) \\
102(100,0) \\
101(99,0)\end{array}$ & $\begin{array}{l}8(7,8) \\
55(53,9) \\
0(0,0) \\
1(1,0) \\
1(1,0) \\
0(0,0) \\
1(1,0)\end{array}$ & $\begin{array}{l}0,782 \\
\mathbf{0 , 0 0 4} \\
1,000 \\
0,317 \\
1,000 \\
1,000 \\
1,000\end{array}$ \\
\hline
\end{tabular}

* Signifikan 
Tidak ada perbedaan porsi konsumsi sayur antara sebelum dengan sesudah pemberian intervensi pada guru $(\mathrm{p}=0,206)$, namun ada perbedaan porsi buah antara sebelum dengan sesudah pemberian intervensi pada guru $(\mathrm{p}=0,004)$. Pada zat gizi, tidak ada perbedaan konsumsi vitamin $A(p=0,782)$, vitamin $B 1(p=1,000)$, vitamin B6 $(p=0,317)$, besi $(p=1,000)$, kalsium $(p=1,000)$ dan fosfor $(p=1,000)$ antara sebelum dengan sesudah pemberian intervensi pada guru, namun ada perbedaan yang bermakna pada kansumsi vitamin $C(p=0,004)$ antara sebelum dengan sesudah pemberian intervensi pada guru.

Tabel 2 memperlihatkan bahwa porsi makan sayur lebih sedikit dibandingkan porsi makan buah. Hasil ini serupa dengan hasil yang ditemukan oleh Young et al. (2013), yaitu anak sekolah lebih banyak mengkonsumsi buah dibandingkan sayur ( $\mathrm{p}<0,0001)$.Menurut Albani et al. (2018), hal ini berkaitan dengan kurang terbangunnya konsep diri anak dalam memotivasi diri sendiri untuk mau makan sayur dan buah sehingga hal ini perlu menjadi perhatian para orang tua. Selain itu, kemudahan dalam mendapatkan buah dibandingkan sayur menjadi pemicu tingginya konsumsi buah dibandingkan sayur seperti adanya penjual buah di sekitar sekolah yang gampang diakses oleh anak sekolah. Penyebab lainnya adalah buah tidak perlu diolah (dimasak) terlebih dulu sehingga gampang dimakan ketimbang sayur yang harus diolah (dimasak) terlebih dulu.

Tingginya konsumsi buah berimbas pada tinggi pula konsumsi zat gizi terutama vitamin C. Dari hasil food recall yang kedua didapatkan anak lebih banyak mengkonsumsi buah jeruk yang merupakan sumber vitamin C. Namun, dapat dikatakan bahwa hampir semua buah mengandung zat gizi vitamin $\mathrm{C}$. Tidak meningkatnya konsumsi zat gizi lainnya (vitamin A, vitamin B1, vitamin B6, besi, kalsium,dan fosfor) sejalan dengan masih rendahnya konsumsi sayur pada siswa. Hal ini menandakan bahwa keragaman konsumsi makanan pada anak sekolah masih rendah. Padahal, usia anak sekolah dianjurkan untuk mengkonsumsi beranekaragam makanan, baik sayur maupun buah untuk memenuhi angka kecukupan gizi yang sesuai dengan karakteristik tumbuh kembang mereka yang relatif cepat.

Penyebab masih rendahnya konsumsi sayur dan buah pada siswa meskipun telah diberikan intervensi pendidikan gizi pada guru sekolah adalah faktor dari dalam keluarga. Gross et al.(2010) menemukan bahwa sekitar 50\% keragaman konsumsi sayur dan buah usia anak sekolah disebabkan oleh faktor keluarga dan lingkungan. Selain itu, faktor frekuensi makan sayur orang tua juga menjadi penyumbang dalam memengaruhi konsumsi sayur pada anak (Kantali, 2016). Aswatini et al. (2008) dan Attorp et al. (2014) menemukan bahwa masih rendahnya pengeluaran keluarga untuk keperluan konsumsi sayur dan buah dibandingkan pengeluaran untuk keperluan makanan dan minuman lainnya. Lebih lanjut, kedua penelitian ini juga menemukan bahwa pengeluaran untuk keperluan konsumsi sayur 
dan buah hampir sama dengan penegeluaran keluarga dalam pembelian tembakau dan sirih.

Faktor keluarga lainnya yang juga menjadi penentu dalam konsumsi sayur dan buah anak adalah pengetahuan ibu. Meskipun kebanyakan ibu telah mengetahui pentingnya sayur dan buah, namun masih belum memiliki pemahaman yang dalam tentang sayur dan buah itu sendiri. Kurangnya motivasi diri dalam menyediakan sayur dan buah serta mengajak anggota keluarga untuk rutin mengkonsumsi sayur dan buah masih menjadi kendala besar bagi kebanyakan ibu rumah tangga di Indonesia (Wulansari, 2009). Hasil penelitian Febrianto dan Rismayanthi(2014) danSartika (2012) menemukan bahwa ibu yang memiliki pengetahuan yang baik tentang makanan yang seimbang tidak kesulitan dalam memilih dan menyediakan makanan yang sesuai dengan kebutuhan anggota keluarganya. Lebih lanjut, konsumsi sayur dan buah anak sangat dipengaruhi oleh pola makan orang tua di rumah karena hal ini berkaitan dengan penyediaan dan kemudahan akses terhadap sayur dan buah yang diberikan oleh orang tua (Ong et al., 2017; Pearson et al., 2009; Wyse et al., 2015).

Faktor lingkungan seperti lingkungan pertemanan juga menjadi penyebab dari pola konsumsi anak usia sekolah. Jika anak berada dalam lingkungan pertemanan yang lebih menyukai jajanan, maka dapat dipastikan bahwa anak akan sangat kurang dalam mengkonsumsi sayur dan buah dikarenakan ketika pulang ke rumah, anak merasa sudah kenyang sehingga tidak mau lagi makan (Proverawati dan Wati, 2014).

\section{KESIMPULAN DAN SARAN}

Pendidikan gizi dapat memenuhi kecukupan konsumsi buah dan vitamin C pada anak sekolah. Namun, belum dapat memenuhi konsumsi sayur dan zat gizi lainnya seperti vitamin A, vitamin B1, vitamin B6, besi, kalsium dan fosfor. Untuk dapat memenuhi kecukupan konsumsi sayur dan buah serta zat gizi anak sekolah, maka pendidikan gizi juga perlu diberikan kepada orang tua, khususnya ibu, sebagai pengolah dan penyedia makanan di rumah.

\section{DAFTAR PUSTAKA}

Albani, V., Butler, L.T., Traill, W.B., dan Kennedy, O.B. 2018. Understanding Fruit and Vegetable Consumption in Children and Adolescent: the Contributions of Affect, Self-Concept and Habit Strength. Appetite, 120(1): 398-408. 
Aswatini, Noveria, M., dan Fitranita, 2008. Konsumsi Sayur dan Buah di Masyarakat dalam Konteks Pemenuhan Gizi Seimbang. Jurnal Kependudukan Indonesia, 3(2): 97-119.

Attorp, A., Scott, J.E., Yew, A.C., Rhodes,R.E., Barr, S.I., dan Naylor, P.J. 2014. Association Between Socioeconomic, Parental and Home Environment Factors and Fruit and Vegetable Consumption of Children in Grades Five and Six in British Columbia Canada. BMC Public Health, 14(1): 150.

Bahria dan Triyanti, 2010. Faktor-Faktor yang Terkait dengan Konsumsi Buah dan Sayur pada Remaja di 4 SMA Jakarta Barat. Jurnal Kesehatan Masyarakat, 4(2): 63-71.

Buamona, E. 2016. Pengaruh Pemberian Pendidikan Gizi melalui Buku Saku dan Ceramah terhadap Pengetahuan Buah dan Sayur pada Anak Sekolah Dasar. Tesis. Universitas Sebelas Maret.

Candra, A.A., Setiawan, B., dan Damanik, M.R.M. 2013. Pengaruh Pemberian Makanan Jajanan, Pendidikan Gizi, dan Suplementasi Besi terhadap Status Gizi, Pengetahuan Gizi, dan Status Anemia pada Siswa Sekolah Dasar. Jurnal Gizi dan Pangan, 8(2): 103-108.

Departemen Gizi dan Kesehatan Masyarakat UI, 2014. Gizi dan Kesehatan Masyarakat. Jakarta: PT Raja Grafindo Persada.

Dwiriani, C.M., Rimbawan, Hardinsyah, Riyadi, H., dan Martianto, D., 2011. Pengaruh Pemberian Zat Multi Gizi Mikro dan Pendidikan Gizi terhadap Pengetahuan Gizi, Pemenuhan Zat Gizi dan Status Besi Remaja Putri. Jurnal Gizi dan Pangan, 6(3): 171-177.

Febrianto, I.D., dan Rismayanthi, C. 2014. Hubungan Tingkat Penghasilan, Tingkat Pendidikan dan Tingkat Pengetahuan Orang Tua tentang Makanan Bergizi dengan Status Gizi. Medikora, 13(1): 1-13.

Gross, S.M., Pollock, E.D., dan Braun, B. 2010. Family Influence: Key to Fruit and Vegetable Consumption among Fourth-and Fifth-Grade Students. J Nutr Educ Behav, 42(4): 235-241.

Hermina, dan Prihatini S. 2016. Gambaran Konsumsi Sayur dan Buah Penduduk Indonesia dalam Konteks Gizi Seimbang: Analisis Lanjut Survei Konsumsi Makanan Individu (SKMI) 2014. Buletin Penelitian Kesehatan, 44(3): 205 218.

Kantali, M. 2016. The Influence of Parental Feeding Practices on the Consumption of Fruit and Vegetables in Preschool-Aged Children. Clinical Nutrition ESPEN, 13 (1): e55. 
Kementerian Kesehatan RI. 2013. Peraturan Menteri Kesehatan RI Nomor 75 Tahun 2013 Tentang Angka Kecukupan Gizi yang Dianjurkan bagi Bangsa Indonesia. Jakarta.

Kementerian Kesehatan RI. 2014a. Riset Kesehatan Dasar 2013. Jakarta.

Kementerian Kesehatan RI. 2014b. Peraturan Menteri Kesehatan Republik Indonesia Nomor 41 Tahun 2014 Tentang Pedoman Gizi Seimbang. Jakarta.

Nurmasyita, Widjanarko, B., dan Margawati, A. 2015. Pengaruh Intervensi Pendidikan Gizi Terhadap Peningkatan Pengetahuan Gizi, Perubahan Asupan Zat Gizi dan Indeks Massa Tubuh Remaja Kelebihan Berat Badan.Jurnal Gizi Indonesia, 4(1): 38-47.

Nuryanto, Pramono, A., Puruhita, N., dan Muis, S.F. 2014. Pengaruh Pendidikan Gizi Terhadap Pengetahuan dan Sikap Tentang Gizi Anak Sekolah Dasar. Jurnal Gizi Indonesia, 3(1): 32-36.

Ong, J.X., Ullah, S., Miller, J., dan Leslie, E. Relationship Between the Home Environment and Fruit and Vegetable Consumption in Children Aged 6-12 Years: a Systematic Review. Public Health Nutr, 20(3): 464-480.

Pearson, N., Biddle, S.J., dan Gorely, T. 2009. Family Correlates of Fruit and Vegetable Consumption in Children and Adolescents: a Systematic Review. Public Health Nutr, 12(2): 267-283

Proverawati, A., dan Wati, E.K. 2014. Ilmu Gizi Untuk Keperawatan dan Gizi Kesehatan. Yogyakarta: Muha Medika.

Sartika, R.A.D. 2012. Penerapan Komunikasi, Informasi, dan Edukasi Gizi terhadap Perilaku Sarapan Siswa Sekolah Dasar. Jurnal Kesehatan Masyarakat Nasional, 7 (2): 76-82.

Supariasa, I.D.N., Bakri, B., dan Fajar, I. 2013. Penilaian Status Gizi. Jakarta: EGC.

Wulansari, N.D. 2009. Konsumsi serta Preferensi Buah dan Sayur pada Remaja SMA dengan Status Sosial Ekonomi yang Berbeda di Bogor. Institut Pertanian Bogor.

Wyse, R., Wolfenden, L., dan Bisquera, A. 2015. Characteristics of the Home Food Environment that Mediate Immediate and Sustained Increases in Child Fruit and Vegetable Consumption: Mediation Analysis from the Healthy Habits Cluster Randomised Controlled Trial. Int J Behav Nutr Phys Act, 12(1):118.

Young, K.D., Snelling, A., Maroto, M., dan Young, K.A. 2013. Consumption of Fruits and Vegetables in Middle School Students Following the Implementation of a School District Wellness Policy. The Journal of Child Nutrition and

Management, 37(2): 1-6 